\title{
Research on the Application of the San Diego Reading Quick Assessment Form in the Teaching of Diagnostic English Reading
}

Zehao Liang

School of Foreign Languages, Guilin Institute of Tourism, Guilin 541006, Guangxi Province, China

Funding: This article is part of the results of the 2017 Guilin Institute of Tourism Talent Training Quality Construction Reform Project: Application Research of Diagnostic English Reading Teaching in Undergraduate English Teaching in Our University (Project No. 2017JGB001).

\begin{abstract}
Based on the theory of diagnostic reading teaching, this article introduces the San Diego quick assessment form and operating methods, and conducts classroom practice for domestic English majors to explore whether the assessment form can improve the reading ability of students under the diagnostic English reading teaching mode Help and influence.
\end{abstract}

Keywords: Diagnostic teaching; English reading; College English; Applied research

Publication date: December, 2020

Publication online: 31 December, 2020

"Corresponding author: Zehao Liang, 229678461@ qq.com

\section{Background}

In 2014, my country wrote the "Advocacy of Reading for All" into the government work report for the first time. This shows that the country attaches great importance to reading, and reading ability is also an important ability that needs to be cultivated in the process of growth. An important way to think and obtain aesthetic experience (The Ministry of Education of the People's Republic of China 2012). In the following years, government work reports also repeatedly mentioned the importance of reading. At the same time, for English subjects, reading teaching is also a way for students to perceive the world. This article uses the San Diego Reading Quick Assessment Form as a platform to study the application of diagnostic reading teaching.

What is diagnostic reading teaching? In 2004, Walker proposed that in reading teaching, it is necessary to know in advance how students read, and then teachers respond to their reading. You can make continuous adjustments during the teaching process while evaluating and teaching to improve students' learning efficiency. This is a very effective method of teaching English reading. The theoretical basis of the diagnostic pedagogy is the theory of constructivist learning, based on the definition that reading and writing are active constructive processes.

In my country, due to the influence of the test baton, test-oriented education is very popular in primary and secondary English teaching. Teachers use traditional foreign language teaching methods, and they often teach about the language (teach about the language), and students learn. It is also learn about the language. Although there was a saying at the 2016 annual conference of the English education industry in my country that "English learning, readers gain the world", the English teaching in colleges and universities mainly revolves around CET- 4 and CET6 , and has not paid much attention to the reading ability of students.

Internationally, research on diagnostic English reading teaching in the United Kingdom and the United States has been very common and mature, especially in the United States. In 1964, Strange published "Diagnostic Teaching of Reading" 
(Diagnostic Teaching of Reading) and Guszak's "Diagnostic Teaching of Reading in Primary Schools" in 1972. "Diagnostic Reading Instruction in the Elementary School". In 1980, "Teaching Elementary Reading" (Teaching Elementary Reading) third edition Karlin's research on "diagnostic reading teaching". Many colleges of education in the United States have opened courses related to diagnostic reading teaching. This is a compulsory course for students engaged in education, and it is also a teaching skill they need to master. In the diagnostic reading teaching, using the San Diego Rapid Assessment Form is a more effective method.

\section{Introduction to San Diego Quick Assessment}

The San Diego Rapid Assessment Form is a graded vocabulary list used to measure students' reading ability. The form of randomly drawn words in the table. (Lepray, M., and Ross, R.1969) This test form is widely used by North American public schools to test the reading level of students. This test form is classified according to grades and is divided into 13 levels, from kindergarten to second grade of high school. Each grade consists of a list of 10 words. The 10 words in the same list are of equal difficulty, and they are all randomly selected from commonly used words.

\section{The application of the San Diego Reading Quick Assessment Form in American English teaching}

Eldon and James introduced that when using the San Diego rapid assessment form in elementary schools in the United States, they usually follow the steps below.

(1) Print out a list of 10 words in each group on the index card, that is, each index card prints 10 words of the same level. For example, Level 2 means 10 words under 2 pairs, our, please, myself, town, early, send, wild, believe, quietly, carefully, etc.

(2) Start with words that are two levels below the student's level. For example, if you are testing a fifthgrade student, start from the third level.

(3) Let the student read the words on the index card. As long as the student reads a word incorrectly, he chooses a lower level word group until the complete correct level appears, which is the basic level, which represents his basic level. For example, a fifth-grade student starts reading from the words of level 3. If he mispronounces a word, he starts reading from the word group of level 2; if the vocabulary of this group is still pronounced incorrectly, he starts from the word group of level 1. Start reading; if he reads all the words in level 1, his basic level is level 1.

(4) Write down all the words he mispronounced and encourage students to read out the words he doesn't understand, judge the students' skills in discerning words, and analyze the reasons for the mispronunciation. For example, the following are some common mistakes: he read back because he reads not as ton; he reads now as how, which is a wrong consonant; he reads straight as state, which is a mispronunciation of consonants; he reads can as cane, which is short There is a problem with the vowel; if wide is pronounced wid, it means that the long vowel is mispronounced; Improve is pronounced as improve, which means that the prefix is mispronounced; improved is pronounced as improve, which means that the suffix is mispronounced; there are other errors such as accents and omissions Festival and so on. After analyzing the causes of these errors, we can find countermeasures to help students improve their ability to decode words.

(5) Ask the student to gradually increase the difficulty of reading words until he reads at least three words incorrectly. For example, if a student in grade 5 reads all the correct words in grade 3, they will read the words in grade 4; in grade 4, they will read the words in grade 5; if they are all correct in grade 5, they will read the words in grade 6; If he reads one or more mistakes, it means that the student's reading level is Level 5, and his reading ability is consistent with his grade level; and if his basic level is Level 6 (read all the words in level 6), it means he The reading level is advanced.

There are many graded reading materials in the United States. After the teacher has passed the test to determine the basic level of the student, according to the teaching needs, he will show the students the books suitable for their grade and quickly improve the students' English reading ability.

\section{Research on the application of the San Diego Reading Quick Assessment Form in the English teaching of Chinese universities}

In this study, in the first class of the English Reading (Extensive Reading) course, students of the college's 
English majors at grades 15, 16 and 17 were tested by the San Diego Rapid Assessment Form. Due to the large number of students in this college, it cannot operate like schools in the United States, so it cannot be tested by reading these words one by one, and then analyzed. According to the actual situation, the study adjusted the operation method, which can also judge the students' reading level more accurately, so as to guide them in extracurricular reading. The main adjustments are as follows:

(1) Print out the San Diego Quick Assessment Form at the beginning of the semester and let the students take a test before the reading class. The test method is to change the reading aloud to translate into Chinese meaning.

(2) Instruct students to analyze their reading level based on test scores. The level where the translation is all right is his basic level, the level where one word is wrong is his independent reading level, the level where two words are wrong is his instruction level, and the level where three or more errors are wrong is too difficult. Level.

(3) Let them recognize their basic level of reading, choose reading materials that suit their own level (independent reading level) according to their reading level, and read one book a week. It is recommended that students use reading apps such as "Good Strategy" to select English books suitable for their level for extracurricular reading, or use the graded reading materials of the library, such as the graded reading materials of the Oxford "Bookworm" series.

(4) Check the students' extensive reading materials in class and make sure that they have chosen books of the right level for extracurricular reading.

(5) At the end of the semester, a second test will be conducted to check whether the students' reading level has improved.

(6) At the end of each semester, students are required to write a summary to find out whether students feel that the San Diego Quick Assessment Form is effective in guiding them to choose extracurricular English books.

\section{Conclusion}

Judging from the students' second test results and self-summary feedback received so far, the reading diagnosis teaching using the San Diego Quick Assessment Form is effective. And we also found in teaching that it is very useful for us to conduct diagnostic reading teaching by testing the reading level of students before class to understand the reading level of students, and to track and analyze them. But at the same time, this research is only limited to the first and second year students of English majors, and there is no further practice among nonEnglish majors and senior English majors. It is hoped that this research can play a role as an inspiration to promote the diagnostic reading teaching and the San Diego rapid assessment form, with a view to more indepth practice and research in the future.

\section{References}

[1] Guszak, Frank J. (1972) Diagnostic Reading Instruction in the Elementary School, Happer \& Row, New York.

[2] Karlin, Robert, (1980)Teaching Elementary Reading, third edition, Harcourt Brace Jovanovich, Inc. 